\title{
KOMUNIKASI BERBANTUAN APLIKASI LECTORA TERHADAP KETERAMPILAN ASUHAN KEHAMILAN DI PROGRAM STUDI D-III KEBIDANAN STIKes KARSA HUSADA GARUT
}

\author{
Fitri Hanriyani $^{*}$, Nizar Alam Hamdani ${ }^{2}$, Hudiana Hernawan ${ }^{3}$ \\ ${ }^{1,2,3}$ Sekolah Pascasarjana Magister Teknologi Pendidikan IPI Garut \\ ${ }^{1}$ Email: fitrihanriyani68@gmail.com
}

\begin{abstract}
ABSTRAK
Ditemukan masalah masih rendahnya kompetensi mahasiswa dalam pemeriksaan HB dengan metode sahli dalam mata kuliah asuhan kehamilan di program studi D-III Kebidanan STIKes Karsa Husada Garut. Teknologi multimedia mampu meberikan kesan yang besar dalam bidang komunikasi dan pendidikan karena dapat mengintegrasikan teks, grafik, animasi, audio dan video. Multimedia telah mengembangkan proses pengajaran. Tujuan penelitian ini adalah untuk mengetahui pengaruh penerapan pembelajaran berbasis multimedia interaktif berbantu aplikasi lectora terhadap peningkatan kompetensi mahasiswa pada pembelajaran asuhan kehamilan di program studi D-III Kebidanan STIKes Karsa Husada Garut. Metode yang digunakan pada penelitian ini adalah metode kuantitatif dengan desain penelitian Eksperimen posttes only berupa intervensi teknik pembelajaran menggunakan multimedia berbantu aplikasi lectora untuk mengetahui pengaruhnya terhadap peningkatan kompetensi mahasiswa pada pembelajaran asuhan kehamilan. Populasi pada penelitian ini adalah seluruh mahasiswa Tingkat I semester II program studi D-III Kebidanan STIKes Karsa Husada Garut dengan jumlah sample 44 mahasiswa ditentukan dengan rumus teknik sampling slovin. Hasil penelitian ini menunjukkan nilai $\mathrm{R}=0.694$ hal ini menunjukan besarnya koefisien korelasi dengan besar pengaruh ditunjukkan oleh R Square (R2) sebesar 0.482. Koefisien korelasi ini termasuk ke dalam kategori kuat. Pembelajaran berbasis multimedia interaktif berbantu aplikasi lectora berpengararuh positif dalam meningkatkan kompetensi mahasiswa pada pembelajaran asuhan kehmailan. Rekomendasi: Disarankan penelitian dan pengembangan produk penelitian lebih lanjut pada meteri yang lebih luas untuk mengetaui pengaruhnya terhadap peningkatan kompetensi mahasiswa.
\end{abstract}

Kata Kunci : Komunikasi’ Interaktif Lectora; peningkatan kompetensi; Mahasiswa

\section{ABSTRACT}

Found the problem is still low student competence in HB examination with sahli method in pregnancy care subject in STIKes Kart Husada Garut Dental Study Program. Multimedia technology is able to give a great impression in the field of communication and education because it can integrate text, graphics, animation, audio and video. Multimedia has developed a teaching process. The purpose of this study is to determine the effect of the application of interactive multimedia-based learning assisted lectora application to increase student competence on learning of pregnancy care in the program D-III Obstetrics STIKes Karsa Husada Garut. The method used in this research is quantitative method with research design Posttes only experiment in the form of learning technique intervention using multimedia assisted lectora application to know its influence to increase student competence on learning of pregnancy care. Population in this research is all students of Level I semester II of D-III Obstetrics of STIKes Karsa Husada Garut with total sample of 44 students determined by slovin sampling technique formula. The result of this research shows that the value of $\mathrm{R}=0.694$ indicates the magnitude of correlation coefficient with big influence shown by R Square (R2) of 0.482. This correlation coefficient belongs to the strong category. Interactive multimedia-based learning assisted lectora application positive effect in improving students' competence on learning care kemmailan. Recommendation: It is advisable to research and develop further research products on a broader meteri to know its effect on increasing student competence.

Keywords : Communication; Lectora Interactive Multimedia; Increased competence' Student 


\section{A. PENDAHULUAN}

Pembangunan kesehatan pada hakekatnya di arahkan guna tercapainya kesadaran, kemauan dan kemampuan hidup sehat bagi setiap orang, menyangkut fisik, mental, maupun sosial budaya dan ekonomi. Untuk mencapai derajat kesehatan yang optimal dilakukan berbagai upaya pelayanan kesehatan yang menyeluruh, terarah dan berkesinambungan. Pendidikan kesehatan merupakan bagian penting dalam pembangunan kesehatan guna menghasilkan sumber daya manusia kesehatan sebagai penggerak pembangunan kesehatan.

Untuk menghasilkan tenaga bidan profesional, terdapat standar kompetensi yang harus dimiliki oleh setiap lulusan, diantaranya mampu memberikan asuhan kebidanan secara efektif, aman dan holistik dengan memperhatikan aspek budaya terhadap ibu hamil, bersalin, nifas dan menyusui bayi baru lahir, balita dan kesehatan reproduksi pada kondisi normal berdasarkan standar praktik kebidanan dan kode etik profesi.

Dalam asuhan kehamilan terdapat beberapa kompetensi yang harus dimiliki oleh setiap mahasiswa, diantaranya pemeriksaan fisik kehamilan dan pemeriksaan penunjang kehamilan, Dalam pemeriksaan penunjang kehamilan terdapat pemeriksaan HB (Hemoglobin) ibu hamil.

STIKes Karsa Husada Garut adalah salah satu penyelenggara pendidikan D-III Kebidanan di Kabupaten Garut. Dalam penyelenggaraan pendidikan tersebut Program studi mengalami beberapa kendala untuk mendapatkan lulusan yang kompeten terutama dalam pemeriksaan laboratorium asuhan kehamilan. Pada evaluasi akhir semester dalam bentuk ujian praktikum mahasiswa banyak yang harus mengikuti remedial dikarenakan hasil ujian praktik mereka dinyatakan belum kompeten, sehingga perlu adanya perbaikan dalam proses pembelajaran.
Berdasarkan pengalaman sementara di STIKes Karsa Husada Garut di temukan permasalahan mengenai masih rendahnya kompetensi mahasiswa dalam pemeriksaan $\mathrm{HB}$ dalam asuhan kehamilan, kegiatan pembelajaran yang masih bersifat konvensional serta belum tepatnya pemanfaatan multimedia pembelajaran.

Lectora inspire adalah sebuah aplikasi pengembangan media berbasis komputer. Aplikasi ini memungkinkan penggabungan unsur teks, gambar, suara, dan video menjadi sebuah multimedia pembelajaran yang interaktif.

Media pembelajaran Lectora inspire mempunyai beberapa keunggulan di bandingkan aplikasi media pembelajaran lainnya, yaitu:

a. Lectora inspire dapat digunakan untuk membuat slide presentasi, media pembelajara, dan presentasi produk.

b. Fitur-fitur yang disediakan lectora inspire sangat memudahkan pengguna pemula untuk membuat multimedia (audio dan video) pembelajaran.

c. Konten yang dikembangkan dengan aplikasi lectora inspire dapat dipublikasikan ke berbagai output seperti HTML5, single file executable (.exe), CD-ROM, maupun standar e-learning seperti SCROM dan AICC.

\section{B. KAJIAN LITERATUR}

Sementara itu, dalam asuhan kehamilan terdapat beberapa kompetensi yang harus dimiliki oleh setiap mahasiswa, diantaranya pemeriksaan fisik kehamilan dan pemeriksaan penunjang kehamilan, dalam pemeriksaan penunjang kehamilan terdapat pemeriksaan HB (Hemoglobin) ibu hamil.

\section{METODOLOGI PENELITIAN}

Metode yang digunakan dalam penelitian ini adalah True Exsperimental Design, PosttestOnly Control Design, Dalam penelitian ini terdapat dua kelompok yang masing-masing dipilih secara random. Kelompok eksperimen diberi perlakuan dengan penerapan pembelajaran berbasis multimedia interaktif lectora dan kelompok kontrol tidak 
diberikan perlakuan. Adapun instrumen yang digunakan adalah daftar tilik pemeriksaan HB dengan metode sahli. Untuk teknik pengumpulan data dalam penelitian ini instrumen yang berupa daftar tilik diperoleh dari observasi dan pengamatan evaluasi praktikum pembelajaran asuhan kehamilan dengan menggunakan multimedia interaktif lectora.

\section{HASIL DAN PEMBAHASAN}

\section{Penerapan pembelajaran berbasis multimedi berbantuan aplikasi lectora pada pembelajaran asuhan kehamilan di Prodi D-III Kebidanan STIKes Karsa Husada Garut}

Setelah menerapkan pembelajaran berbasis multimedia berbantuan aplikasi Lectora pada pembelajaran asuhan kehamilan, selanjutnya dilakukan tes Evaluasi Kompetensi Pemeriksaan $\mathrm{Hb}$ Sahli yang dilakukan sebanyak 4 kali. Adapun hasil yang diperoleh, yaitu rata-rata/mean Evaluasi Kompetensi Pemeriksaan $\mathrm{Hb}$ Sahli ke 1 sebesar 53,77 dengan nilai terkecilnya 21,00 dan terbesarnya 74,00, serta simpangan baku sebesar 9,951, frekuensi nilai yang paling besar, yaitu 47 sebanyak 9 mahasiswa (20,9\%), sedangkan frekuensi nilai yang paling kecil, yaitu 21 dan 31 masing-masing 1 mahasiswa $(2,3 \%)$.

Selanjutnya, rata-rata/mean Evaluasi Kompetensi Pemeriksaan Hb Sahli ke 2 sebesar 63,57 dengan nilai terkecilnya 42,00 dan terbesarnya 80,00 , serta simpangan baku sebesar 9,782, frekuensi nilai yang paling besar, yaitu 58 dan 68 sebanyak 10 mahasiswa $(22,7 \%)$, sedangkan frekuensi nilai yang paling kecil, yaitu 42 dan 47 masing-masing 2 mahasiswa (4,5\%). Rata-rata/mean Evaluasi Kompetensi Pemeriksaan Hb Sahli ke 3 sebesar 71,16 dengan nilai terkecilnya 42,00 dan terbesarnya 89,00 , serta simpangan baku sebesar 12,56, frekuensi nilai yang paling besar, yaitu 80 sebanyak 14 mahasiswa $(31,8 \%)$, sedangkan frekuensi nilai yang paling kecil, yaitu 53, 58, dan 89 masing-masing 1 mahasiswa (2,3\%). Rata-rata/mean Evaluasi Kompetensi Pemeriksaan $\mathrm{Hb}$ Sahli ke 4 sebesar 82,84 dengan nilai terkecilnya 58,00 dan terbesarnya 95,00 , serta simpangan baku sebesar 8,69, frekuensi nilai yang paling besar, yaitu 80 sebanyak 12 mahasiswa $(27,3 \%)$, sedangkan frekuensi nilai yang paling kecil, yaitu 58 dan 68 masing-masing 2 mahasiswa $(4,5 \%)$.

Selanjutnya, dari keempat tes Evaluasi Kompetensi Pemeriksaan $\mathrm{Hb}$ Sahl dibuat grafik yang hasilnya dapat dilihat pada gambar di bawah ini.

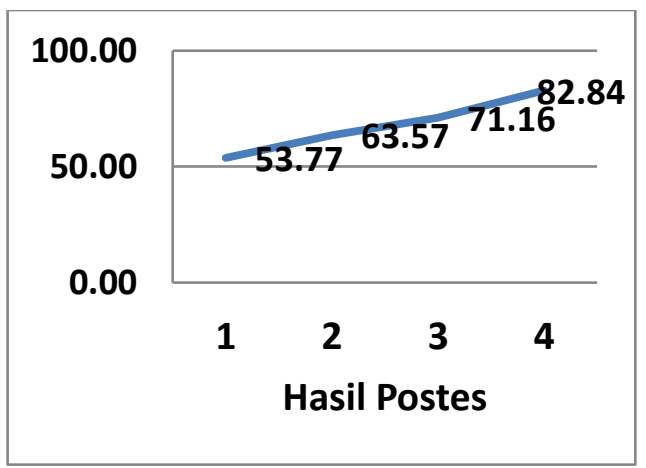

Gambar 1. Hasil Postes

Berdasarkan gambar di atas, tampak penerapan pembelajaran berbasis multimedia berbantuan aplikasi Lectora memperoleh ratarata yang terus meningkat, sehingga dapat disimpulkan bahwa penerapan pembelajaran berbasis multimedia lectora dapat meningkatkan Kompetensi Pemeriksaan $\mathrm{Hb}$ Sahli mahasiswa dan menunjukan hasil yang meningkat secara konsisten.

Seperti diketahui, Pendidikan Diploma III Kebidanan merupakan pendidikan vokasional yang menghasilkan tenaga bidan profesional pada tingkat Ahli Madya yang lulusannya mendapat gelar Ahli Madya Kebidanan yang mampu berperan sebagai Care Provider (Pemberi asuhan kebidanan), Comminity Leader (Penggerak masyarakat), Communicator (komunikator), Decision Maker ( Pengambilan keputusan dalam asuhan kebidanan) dan manager (pengelola).

Untuk menghasilkan tenaga bidan profesional, terdapat standar kompetensi yang harus dimiliki oleh setiap lulusan, diantaranya mampu memberikan asuhan 
kebidanan secara efektif, aman dan holistik dengan memperhatikan aspek budaya terhadap ibu hamil, bersalin, nifas dan menyusui bayi baru lahir, balita dan kesehatan reproduksi pada kondisi normal berdasarkan standar praktik kebidanan dan kode etik profesi.

Selanjutnya, yang dimaksud kompetensi bidan meliputi pengetahuan, keterampilan dan perilaku yang harus dimiliki oleh seorang bidan dalam melaksanakan praktik kebidanan secara aman dan bertanggung jawab pada berbagai tatanan pelayanan kesehatan. Kompetensi tersebut dikelompokkan dalam 2 (dua) kategori yaitu kompetensi inti/dasar merupakan kompetensi minimal yang mutlak dimiliki oleh bidan, kompetensi tambahan/lanjutan merupakan pengembangan dari pengetahuan dan keterampilan dasar untuk mendukung tugas bidan dalam memenuhi tuntutan atau kebutuhan masyarakat yang sangat dinamis serta perkembangan IPTEK.

Sementara itu, dalam asuhan kehamilan terdapat beberapa kompetensi yang harus dimiliki oleh setiap mahasiswa, diantaranya pemeriksaan fisik kehamilan dan pemeriksaan penunjang kehamilan, dalam pemeriksaan penunjang kehamilan terdapat pemeriksaan HB (Hemoglobin) ibu hamil.

Menyoroti hasil penelitian pada paparan di atas, tampak bahwa kompetensi mahasiswa semakin meningkat dengan diterapkannya multimedia berbantuan aplikasi Lectora, dari 44 mahasiswa yang mengikuti tes evaluasi kompetensi menunjukkan bahwa pada tes ke 1 hingga tes ke 4 nilai hasil evaluasi kompetensi mahasiswa terus meningkat, pada tes ke 1 hasil evaluasi kompetensi mahasiswa dari rata-rata 53,77 meningkat pada tes ke 2 menjadi rata-rata 63,57, dari tes ke 2 meningkat pada tes ke 3 menjadi rata-rata 71,16 , selanjutnya dari tes 3 meningkat pada tes ke 4 menjadi rata-rata 82,82 . Hasil penelitian ini membuktikan bahwa fungsi dan manfaat penggunaan multimedia berbantuan aplikasi Lectora dapat menambah gairah belajar mahasiswa yang pada gilirannya meningkatkan hasil belajar (kompetensi), begitupun proses pembelajarannya menjadi lebih menarik dan kualitas pembelajaran dapat ditingkatkan, kondisi ini sesuai dengan pendapat Sanjaya. Berkembangnya ilmu dan teknologi, membawa perubahan pula pada learning matterial atau bahan belajar. Sebelum berkembangnya teknologi komputer bahan belajar yang pokok digunakan dalam dunia pendidikan, khususnya di Prodi D-III Kebidanan STIKes Karsa Husada Garut adalah semua yang bersifat printed matterial, seperti halnya buku, modul makalah, jurnal, hand out lifte, dan sebagainya yang semuanya menggunakan bahan tercetak. Adanya perubahan dalam bidang teknologi khususnya teknologi informasi, membawa paradigma baru pada learning matterial dan learning method. Produk TI dewasa ini telah memberikan alternatif berupa bahan belajar yang dapat digunakan dan diakses oleh mahasiswa yang tidak dalam bentuk kertas, tetapi berbentuk multimedia berbantuan aplikasi Lectora seperti yang dilakukan pada penelitian ini.

\section{Persepsi mahasiswa terhadap multimedia berbantuan aplikasi Lectora pada matakuliah asuhan kehamilan di Prodi D-III Kebidanan STIKes Karsa Husada Garut}

Berdasarkan hasil penelitian, dengan menggunakan scale semantic differential tampak persepsi siswa terhadap pembelajaran berbasis multimedia berbantuan aplikasi Lectora berada pada kutub positif, artinya mahasiswa menilai positif atau baik pembelajaran berbasis multimedia berbantun aplikasi Lectora yang digunakan pada penelitian ini. Makna positif tanggapan siswa ini, setelah dilakukan pengskoran tampak rata-rata persepsi mahasiswa terhadap pembelajaran berbasis multimedia berbantun aplikasi Lectora ini adalah sebesar 83 yang termasuk pada kriteria "Sangat Sangat Baik".

Pada penelitian ini, mahasiswa yang belajar menggunakan CAI (Computer Assited Instruction) sebagai suplemen menunjukkan hasil yang lebih baik. Hal ini didukung pula 
oleh karakter mahasiswa saat ini yang tergolong digital natives (tumbuh dan berkembang dalam lingkungan teknologi informasi).

Selanjutnya, pada penelitian ini, pembelajaran multimedia merupakan model yang menggabungkan teknologi untuk memfasilitasi dosen dan mahasiswa dalam meningkatkan proses pembelajaran. Multimedia dapat meningkatkan kapasitas working memory, yakni kemampuan otak untuk memproses informasi. Otak dapat memproses informasi dengan cepat apabila informasi yang disajikan dalam bentuk visual dan verbal.

Pembelajaran multimedia berbantuan aplikasi Lectora pada matakuliah asuhan kehamilan juga dapat membantu dosen dalam menciptakan pembelajaran yang lebih baik. Selain itu, pembelajaran multimedia berbantuan aplikasi Lectora pada matakuliah asuhan kehamilan dapat mengakomodir mahasiswa dengan kecerdasan ganda melalui multimedia interaktif seperti yang dikemukakan oleh Bull (2013). Melalui pembelajaran multimedia, dosen memfasilitasi mahasiswa untuk belajar menghubungkan informasi baru ke dalam sistem kognitif mereka dan membuatnya paham.

Oleh karena itu, salah satu keberhasilan perkuliahan dapat dilihat dari persepsi dan sikap mahasiswa dalam pembelajaran. Pengetahuan tentang mahasiswa dan karakter mahasiswa merupakan salah satu faktor penentu keberhasilan pembelajaran. Berdasarkan hasil di atas ada beberapa hal yang perlu diperhatikan dalam proses pembelajaran. Proses pembelajaran merupakan suatu sistem yang terdiri dari beberapa komponen yang saling berinteraksi, berhubungan dan bergantung satu sama lain. Untuk menciptakan proses pembelajaran yang ideal yang perlu dilakukan oleh seorang dosen dalam proses belajar mengajar, yaitu harus terjadi I.2, yaitu interaktif dan inspiratif serta M.3 yaitu menyenangkan, menantang, dan memotivasi mahasiswa untuk berpartisipasi aktif. Kondisi ini sesuai dengan yang dilakukan pada penelitian ini.

\section{Pengaruh penerapan pembelajaran berbasis multimedia interaktif berbantuan aplikasi Lectora terhadap kompetensi mahasiswa pada pembelajaran asuhan kehamilan di Prodi D-III Kebidanan STIKes Karsa Husada Garut}

Untuk mengetahui pengaruh penerapan pembelajaran berbasis multimedia interaktif berbantuan aplikasi Lectora terhadap kompetensi mahasiswa, telah dilakukan uji Korelasi dan Regresi untuk mengetahui pengaruh persepsi mahasiswa terhadap kompetensi mahasiswa. Berdasarkan hasil perhitungan, dihasilkan nilai $\mathrm{R}=0.694$, hal ini menunjukkan besarnya koefisien korelasi, yaitu nilai hubungan antara persepsi mahasiswa dengan kompetensi mahasiswa sebesar 0.694 atau $69,4 \%$ dengan besar pengaruh ditunjukkan oleh R Square (R2) sebesar 0.482 atau $48.2 \%$. Koefisien korelasi yang diperoleh termasuk ke dalam kategori kuat.

Selanjutnya setelah dilakukan uji ANOVA dihasilkan koefisien korelasi yang signifikan, karena nilai Sig. $0.000<\alpha(0.05)$ yang berarti terdapat hubungan yang signifikan antara variabel persepsi mahasiswa dengan kompetensi mahasiswa. Adapun persamaan regresi yang dihasilkan adalah sebagai berikut: $\mathrm{Y}=70.978+7.789 \mathrm{X}$. Variabel independen naik atau berpengaruh dalam satu satuan, maka variabel kompetensi mahasiswa akan naik atau terpenuhi. Selanjutnya, persepsi mahasiswa mengalami kenaikan satu satuan, maka kompetensi mahasiswa akan mengalami peningkatan sebesar 7.789 atau $77.89 \%$ dan kenaikan persepsi mahasiswa akan mengakibatkan kenaikan pada kompetensi mahasiswa.

Berdasarkan hasil penelitian, diketahui bahwa pada pembelajaran berbasis multimedia interaktif berbantuan aplikasi Lectora membuat mahasiswa senang dan termotivasi dalam belajar, menyenangkan dan menarik selama pembelajaran serta memahami materi yang disajikan dalam multimedia interaktif berbantuan aplikasi 
Lectora. Selain itu, pembelajaran berbasis multimedia interaktif berbantuan aplikasi Lectora meningkatkan partisipasi aktif mahasiswa dan memudahkan mahasiswa dalam memahami materi secara mandiri. Hal tersebut sesuai dengan pernyataan Smaldino, dkk. (2005) mengenai keuntungan penggunaan multimedia. Menurutnya, multimedia memberikan kesempatan kepada mahasiswa untuk terlibat aktif dalam pembelajaran dan memberikan kesempatan kepada mahasiswa untuk belajar secara mandiri dan berulangulang.

Hasil penelitian juga menunjukkan bahwa adanya gambar, animasi dan video membantu pemahaman mahasiswa terhadap materi yang disampaikan. Menurut Mayer (2003) mahasiswa akan belajar lebih dalam dari teks dan gambar daripada teks saja. Moreno \& Duran (2004) menambahkan bahwa hal tersebut karena pengetahuan yang diproses dari dua saluran lebih besar daripada yang diproses dari satu saluran. Menurut Smaldino dkk. (2005), program animasi dalam multimedia dapat dimanfaatkan untuk menunjukkan simulasi proses dinamis suatu objek konkret maupun abstrak, sehingga memberikan pengalaman belajar yang lebih bermakna dengan seolaholah melihat secara langsung objek yang sedang dipelajari. Penggunaan gambar, animasi dan video atau yang biasa disebut multimedia dapat membantu pemahaman mahasiswa terhadap materi perkuliahan, karena dengan penggunaan berbagai multimedia representasi tentang Pemeriksaan $\mathrm{Hb}$ Sahli dapat ditampilkan secara maksimal. Ketika hubungan elemen multimedia terbentuk dalam representasi tersebut, mahasiswa lebih mudah memahami dan mudah belajar yang pada gilirannya meningkatkan kompetensi mahasiswa tentang Pemeriksaan $\mathrm{Hb}$ Sahli.

Berdasarkan paparan di atas, pembelajaran berbasis multimedia interaktif berbantuan aplikasi Lectora berpengaruh positif dalam meningkatkan kompetensi mahasiswa. Hal ini dikarenakan bahan ajar multimedia membuat mahasiswa senang dan termotivasi dalam belajar, menyenangkan dan menarik selama pembelajaran, meningkatkan partisipasi aktif mahasiswa, dan memudahkan mahasiswa dalam memahami materi secara mandiri, selain itu adanya gambar, animasi dan video membantu pemahaman mahasiswa terhadap materi yang disampaikan.

\section{E. KESIMPULAN}

Berdasarkan hasil penelitian, maka dapat ditarik kesimpulan sebagai berikut: Penerapan pembelajaran berbasis multimedia interaktif berbantu aplikasi lectora pada pembelajaran asuhan kehamilan di Prodi D-III kebidanan STIKes karsa Husada Garut sudah dilaksanakan dan sesuai dengan rencana yaitu dilakukan evaluasi sebanyak empat kali dengan hasil peningkatan kompetensi yang terus meningkat. Persepsi mahasiswa terhadap pembelajaran berbasis multimedia interaktif berbantu aplikasi lectora mendapat penilaian sangat baik dari mahasiwa program studi D-III kebidanan STIKes Karsa Husada Garut. Pembelajaran berbasis multimedia interaktif berbantu aplikasi lectora berpengaruh positif dalam meningkatkan kompetensi mahasiswa pada pembelajaran asuhan kehamilan.

\section{F. REFERENSI}

Ari Arikunto, Suharsimi.(2009). Manajemen Penelitian. Jakarta : Bumi Aksara.

(2006). Prosedur penelitian suatu pendekatan praktik. Jakarta : Rineka Cipta.

Alamsyah, Rudi. (2015). Pengaruh Penggunaan Media Pembelajaran Komputer I-Spring Presenter untuk Meningkatkan Motivasi Belajar dan Hasil Belajar Pada Mata Kuliah Keperawatan Dasar : Nutrisi di STIKes Karsa Husada Garut. Tesis.

Darmawan, Deni. (2013). Teknologi Pembelajaran. Bandung: Rosda.

Darmawan, Deni. (2014). Inovasi Pendidikan. Bandung: Rosda. 
Darmawan, Deni. (2014). Pengembangan E- Learning Teori dan Desain. Bandung: Rosda.

Kemenkes RI. (2011). Kurikulum Inti Kebidanan. Jakarta.

Kuswanti, Ina. (2014). Asuhan Kehamilan. Yogyakarta. Pustaka Belajar.

N.K, Roestiyah. (2012). Stategi Belajar Mengajar. Jakarta. Rineka Cipta.

Riduwan. (2007). Belajar mudah penelitian untuk guru, karyawan dan peneliti pemula. Bandung : Alfabeta.

STIKes Karsa Husada Garut. (2015). Laporan Hasil Belajar.

Sugiono.(2009). Statistik untuk penelitian. Bandung: Alfabeta.

Sugiono, (2016). Metode Penelitian Kualitatif, Kuantitatif dan R\&D. Bandung: Alfabeta

Sudjana, dkk. (2011). Media Pengajaran. Bandung. Sinar Baru Algensindo.

Sumber Internet:

file:///F:/modul-ispring-presenter.pdf.

Diakses tanggal 10 Februari 2017 jam 22.38 WIB 